\title{
Research on the Implementation Countermeasures of Humanistic Quality Education for College Students in Science and Engineering Colleges
}

\author{
Qiyu Sun \\ China Jiliang University \\ Hangzhou, China
}

\begin{abstract}
The 16th National Congress of the Communist Party of China clearly stated the tasks and objectives of cultivating high-quality talents in higher education institutions. The science and engineering colleges have been focusing on cultivating students' science and engineering expertise and skills, ignoring students' humanistic quality education. Therefore, it is of great practical significance to strengthen the research on humanities quality education for college students of science and engineering colleges. This paper puts forward the specific implementation countermeasures for the status quo of humanistic quality education in science and engineering colleges by analyzing the necessity of humanistic quality education.
\end{abstract}

Keywords-science and engineering colleges; college students; humanities quality; countermeasures

\section{INTRODUCTION}

In an international environment where competition is more comprehensive, higher education is in a revolution. The number of students with higher education worldwide is expected to increase from 28 million in 1970 to 262 million in 2025. This growth rate represents a huge increase in global demand for higher education. This demand is driven by far-reaching political, economic, social and technological changes. It requires that the educational level of college students, including economics, society, innovation, and quality education for college students be fully implemented. In the science and engineering colleges lacking humanistic quality education, how to combine the characteristics of science and engineering disciplines with the characteristics of science and engineering students, and explore the corresponding humanistic quality education countermeasures is the subject of this paper. Promoting the improvement of humanities quality of science and engineering students is the necessary path to train high-quality talents.

\section{HUMANISTIC QUALITY EDUCATION}

\section{A. The connotation of humanistic quality education}

The word "humanity" first appeared in "Zhou Yi", "Bi", "civilization, humanity, and modification." "Ci Hai" wrote: "Humanism refers to various cultural phenomena in human society." Humanity is the advanced and core part of human culture, that is, advanced values and norms. As for quality education, the "Management Dictionary" (Second Edition) published in 1997, the first income "quality education" remarks, defined as "China's decision to implement in the basic education stage to promote the overall development of students' quality Education of purpose".

Humanities education (also known as People-oriented education) is an educational method represented by human psychologists Abraham Maslow and Carl Rogers. Beginning in the 1970s, according to the theory of second language teaching, the recipient of education was first considered a person and then considered a learner. As Lei (2007) said, humanistic education based on humanistic education emphasizes the importance of the inner world of the learner. The learner places the individual's thoughts, emotions and emotions at the forefront of human development. True modern education is not like the traditional tradition of authoritarian education. It focuses on the mathematical and physical world. The humanistic quality should be a person's inner cultivation and moral quality. It is a way to guide people to correctly understand themselves and cultivate good people to form a correct and scientific outlook on life, values and world views.

Based on the main principles and characteristics of the humanities education mentioned above, it is obvious that this is a special focus on the emotional and emotional effects of students. Their cognitive and linguistic abilities play a vital role in the language learning process. These principles have changed the previous teacher-centered classroom teaching model and guided the development of education. In this process, learners are the key. As a result of this new focus, all aspects of major changes have taken place in language education. To clarify this point, the next section will describe in detail the main teaching implications and applications of the human approach. The educational connotation of humanities education One of the main goals of educational practice has 
been mentioned by many scholars and is a critical thinking that encourages students.

\section{B. The necessity of implementing humanistic quality education}

The university stage is an important turning point in life, because this period is not only an important stage in the rapid development of a person's physiology and psychology, but also a transitional period in which individual psychology tends to show the maturity of the self and is not yet fully mature. To find a good job is the goal of graduation. Then, people with good quality education have more opportunities to find a good job with high salary, and work is the primary goal of the students who leave the university. Everyone wants a good life, except for a good life. Although it may be called the "source of all evils", most people will agree that in today's world, money is very important for survival. The higher your education, the better your career choices. At the same time, quality education is a necessity for us to eliminate the differences between different social classes and genders. It opens up a world full of opportunities for the poor, giving them equal access to high-paying jobs. Education also plays an important role in empowering women. The most important thing is that quality education affects our understanding of right and wrong to a large extent. An educated person is well aware of the consequences of mistakes and illegal actions. He is unlikely to be affected and does something legally and morally incorrect.

\section{ThE STATUS QUO OF HUMANISTIC QUALITY EDUCATION IN UNIVERSITIES OF SCIENCE AND ENGINEERING}

\section{A. The status quo of humanistic quality education}

The education of humanistic quality is to link humanity with science and technology. In addition, some uneducated people live a life of poverty because of lack of opportunities. They often resort to illegal ways such as theft and robbery to solve their problems. If you are educated, you will be well aware of your rights, laws and responsibilities to society. Therefore, education is an important factor in promoting social harmony and peace. At present, China's science and engineering colleges ignore humanistic quality education mainly in the following two aspects:

\section{a) The school does not pay enough attention}

Whether in the discipline construction or in the professional training program, the school considers the problem from the perspective of professional skills, and often considers the teaching and training of the students' practical skills, and ignores the students' humanistic quality education. Although many science and engineering colleges offer humanities courses such as philosophy, literature, and art for students, the content of the course is boring, not new, and the class is too small and too formal. This shows that the science and engineering colleges have a better understanding of humanistic quality education. Stay on the surface.

Insufficient humanities knowledge Enough professional training mode has long influenced China's higher education. Many universities, especially science and engineering universities that focus on science and engineering, focus on professional education, neglect humanistic quality education and are influenced by the market economy. It has become a guide to the rapid success of students. These impetuous and superficial academic atmospheres have seriously affected the cultivation of talents. Especially in the employment distribution system of colleges and universities, the employment rate of students is an important indicator of teaching.

In order to prove their ability and teaching level, many colleges and universities in order to pursue higher employment rates, some universities only pay attention to the cultivation of professional skills and despise humanistic quality education. However, in fact, improving the quality of human beings is one of the requirements for improving the quality of human beings. This is especially true for the cultivation of students in colleges and universities. In colleges and universities, there is a problem of lack of humanistic quality education for students. There is no solid academic foundation. All the time and energy are spent on the study profession. Those who rarely learn humanities knowledge are also biased towards the planning of the university.

\section{b) Students of science and engineering colleges are} biased towards the discipline of humanities

In most science and engineering colleges, many students believe that humanities science is a rote science, but it is only talkative about it, and it does not play a substantive role in solving specific problems. Most students of the Polytechnic Institute, especially those majoring in science and engineering, have always believed that the humanities are boring, the classroom atmosphere is poor, the teaching content is boring and has no effect on their employment and future development. Personal ethics is very important for college students. Good moral quality and strict personal integrity can guarantee a stable life and enable students to become the pillars of society. But the problem now is the moral deviation of college students. Students are becoming more and more serious about learning so-called professional knowledge, and fewer and fewer students do not think morality is correct. Lack of knowledge of Chinese traditional culture and poor language skills. The mere focus on the development of professional knowledge and skills does not really meet the needs of practical work.

According to some scholars, the goal of humanities education goes beyond cognitive education and intellectual education to accept the education of the whole person. It focuses on the growth of personal growth and creativity, and learns to some extent. The end of education is the same as the end of psychotherapy: creating a completely normal person. Accepting the experience, an existing lifestyle in which life is a continuous, flexible, adaptive process, and a change in the characteristics of a person with learning and responsiveness in an organism that is the basis of behavior. Some scholars believe that the characteristics of humanities education are student-centered, and the goal is not to focus on students, not only to cultivate learners' cognitive and language skills, but also to learn the learners' language skills. 


\section{B. Cause Analysis}

\section{a) The school's humanities are insufficiently accumulated}

Colleges and universities of science and engineering, the construction of their own schools is biased towards the cultivation and development of scientific quality, and often neglect the cultivation of students' comprehensive quality must combine human quality with scientific quality. The loss of the seat thoughts of many college students is due to the correct track of their moral understanding. It exposes many ideological and moral problems. College students must develop good moral character, and have a good desire to become a qualified successor to the socialist cause, not only relying on ideological and political education. To solve the problem practically, but also to be people-oriented. Therefore, the curriculum of humanities quality is less open, and the allocation of humanities teachers in science and engineering colleges is weak, and it is impossible to implement a perfect humanistic quality education. Many engineering colleges are simple and casual in the form of setting up and managing humanities quality courses. Therefore, the curriculum of humanities quality is less open, and the allocation of humanities teachers in science and engineering colleges is weak, and it is impossible to implement a perfect humanistic quality education.

\section{b) Science and engineering students have low interest} in humanities

Most of the students in science and engineering are science students in high school, and the traditional "reconciliation of light texts" is hard, which leads students to pay less attention to humanities courses. The logical thinking of science and engineering is also different from the humanities curriculum, so students' acceptance and mastery of humanities are affected. The classroom atmosphere of humanities is not like the multi-experimental and hands-on practice of science and engineering. More language expression ability is mainly discussed in the form of discussion and exchange of ideas. This is also the result of most science and engineering students. The main reason for the lack of interest in the discipline.

\section{COUNTERMEASURES FOR THE IMPLEMENTATION OF HUMANISTIC QUALITY EDUCATION IN UNIVERSITIES OF SCIENCE AND ENGINEERING}

\section{A. School leaders and teachers have increased their attention and increased their cultural activities on campus}

First of all, the teachers of science and engineering colleges should fully understand the importance and urgency of strengthening the humanities quality education in science and engineering colleges. In the curriculum setting, a certain number of humanities quality compulsory courses and elective courses should be added. In the curriculum content of the humanities quality curriculum, we combine the characteristics of the times and the interests of students, and try to integrate multidisciplinary forces. Therefore, it can adjust and improve students' prejudice on the humanities quality education curriculum, and cultivate the role of improving the humanities quality of college students.
Secondly, the school can also implement the special lecture on humanistic quality education. In an institution of higher learning such as a university, the scope of academic lectures it conducts must be very broad and involve all aspects of knowledge. Therefore, in order to strengthen the humanities quality of students, science and engineering colleges should provide special lectures on humanistic quality education as an important carrier to provide students with new ideas, new methods and new knowledge in the humanities field. Inviting off-campus experts to come to the school to make a special report on humanistic quality education is also a good method.

The acquisition of knowledge is another important situational shift. With the advent and development of the new media era, teachers of schools and literati quality courses should also actively use the Internet platform to use the new media means to carry out quality education work in the form and method that college students like to hear.

\section{B. Strengthen students' understanding of the humanistic quality education and learning initiative}

Some students themselves pay insufficient attention to the cultivation of humanistic qualities. The utilitarianism in subjective consciousness is too strong. The concept of life and values of money worship is rampant, and the practical role and significance of humanistic quality training are neglected. College students should understand that humanities quality plays a fundamental role in the cultivation of college students' comprehensive quality. To improve the current situation of weak humanities education in science and engineering colleges, it is necessary to guide the students of science and engineering disciplines to strengthen the self-education awareness of humanities quality education. Not only do colleges and universities focus on the study of great scientists, social reformers, and other constructive geniuses, they just praise writers, humanist philosophers, and religious believers who have a lasting belief in spiritual values, but rather these humanities. Workers also study hard, because only these educated people are the true benefactors of human beings.

Students can realize the positive creation of conditions through the exploration of characteristic cultural quality education according to the theory of quality education, and combine the functions created by students themselves to play the functions of the society and invite students of humanities to freely organize the development of social practice activities. In this way, college students are encouraged to shape themselves according to their internal needs, and finally realize the improvement of humanities quality and comprehensive quality.

Students can also participate spontaneously in the research projects of teachers, and a sound education system encourages innovation. Education should motivate the best of the student, not killing his thoughts. Through the development of scientific research projects, students can better understand the rationale that humanities and science and technology do not separate families. There are necessary links between different disciplines. The improvement of humanities quality is also very helpful for students' science and engineering projects. Thus, the mitigation of the humanities is a misunderstanding of "death" or a prejudice of "re-consideration of literary works." 


\section{CONCLUSION}

With regard to the implementation of humanities quality education in science and engineering colleges, we must first clarify the school's training objectives for students' quality education and adhere to the principle of "student-oriented". Undergraduate colleges in the new era are pursuing the comprehensive development of students and the improvement of comprehensive quality. Education not only makes people literate, but of course literacy is important for children or adults. What's more important is that an educated person should have unlimited curiosity, use scientific methods to understand and understand the enthusiasm of things, and be completely objective. This paper analyzes the current situation of humanities quality education for students in science and engineering colleges and emphasizes that it is inseparable from the cooperation of all parties in strengthening the implementation of humanistic quality education. The humanistic quality education in science and engineering colleges is a topic of far-reaching significance, and it is also a long-term task. It requires more theoretical research scholars engaged in ideological and political education, and teachers who are specifically working as students in science and engineering colleges. In order to make it continue to improve and long-lasting effective operation.

\section{REFERENCES}

[1] Cao Wenbo. Analysis of Humanities Quality Education in Engineering Colleges[J].Education Review,2015(02):44-46

[2] Xiao Zongliu. Why should colleges apply "quality education" [J]. Jiangsu Higher Education, 1999, (1)

[3] Tu Gangpeng, Fu Ruoyun. Analysis on the Education of College Students' Humanities Quality with the Teaching of Ideological and Political Theory Courses[J]. School Party Construction and Ideological Education, 2015(23): 48-50.

[4] Yang Lina, Lin Qing. Research on the Status Quo and Improvement Strategies of Humanities Education for College Students in Engineering Colleges[J]. Science and Technology, 2014(08): 199- 200.

[5] Zhang Xuerong, Xu Linping, Cao Xiling. Thoughts on Optimizing the Management of Humanities Quality Education in Engineering Colleges[J]. Education Review, 2015(01): 37-39.

[6] Feng Shuo. The Importance of Humanity Quality Education in Ideological and Political Education in Engineering Colleges[J]. Education and Occupation, 2010(14): 76-77.

[7] Zhang Zecheng. Countermeasure Research on Humanities Quality Education of Normal University Students[D]. Northeast Normal University, 2017.

[8] Liu Dongying. Exploration of College Students' Humanities Quality Education under the Background of New Engineering[J]. University Teaching in China, 2018(11):26-29. 